\title{
Front Matter: Volume 9968
}

, "Front Matter: Volume 9968," Proc. SPIE 9968, Hard X-Ray, Gamma-Ray, and Neutron Detector Physics XVIII, 996801 (23 November 2016); doi:

$10.1117 / 12.2258518$

SPIE Event: SPIE Optical Engineering + Applications, 2016, San Diego, California, SPIE. United States 


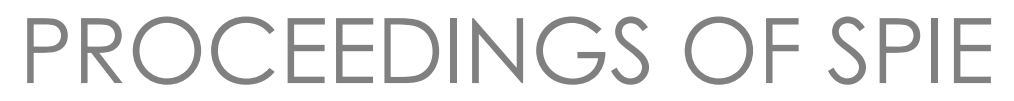

\title{
Hard X-Ray, Gamma-Ray, and Neutron Defector Physics XVIII
}

\author{
Ralph B. James \\ Michael Fiederle \\ Arnold Burger \\ Larry Franks \\ Stephen A. Payne \\ Editors
}

29-31 August 2016

San Diego, California, United States

Sponsored and Published by

SPIE 
The papers in this volume were part of the technical conference cited on the cover and title page. Papers were selected and subject to review by the editors and conference program committee. Some conference presentations may not be available for publication. Additional papers and presentation recordings may be available online in the SPIE Digital Library at SPIEDigitallibrary.org.

The papers reflect the work and thoughts of the authors and are published herein as submitted. The publisher is not responsible for the validity of the information or for any outcomes resulting from reliance thereon.

Please use the following format to cite material from these Proceedings:

Author(s), "Title of Paper," in Hard X-Ray, Gamma-Ray, and Neutron Detector Physics XVIII, edited by Ralph B. James, Michael Fiederle, Arnold Burger, Larry Franks, Stephen A. Payne, Proceedings of SPIE Vol. 9968 (SPIE, Bellingham, WA, 2016) Six-digit Article CID Number.

ISSN: 0277-786X

ISSN: 1996-756X (electronic)

ISBN: 9781510603271

ISBN: 9781510603288 (electronic)

Published by

SPIE

P.O. Box 10, Bellingham, Washington 98227-0010 USA

Telephone +1 3606763290 (Pacific Time) · Fax +13606471445

SPIE.org

Copyright (C) 2016, Society of Photo-Optical Instrumentation Engineers.

Copying of material in this book for internal or personal use, or for the internal or personal use of specific clients, beyond the fair use provisions granted by the U.S. Copyright Law is authorized by SPIE subject to payment of copying fees. The Transactional Reporting Service base fee for this volume is $\$ 18.00$ per article (or portion thereof), which should be paid directly to the Copyright Clearance Center (CCC), 222 Rosewood Drive, Danvers, MA 01923 . Payment may also be made electronically through CCC Online at copyright.com. Other copying for republication, resale, advertising or promotion, or any form of systematic or multiple reproduction of any material in this book is prohibited except with permission in writing from the publisher. The CCC fee code is 0277-786X/16/\$18.00.

Printed in the United States of America.

Publication of record for individual papers is online in the SPIE Digital Library.

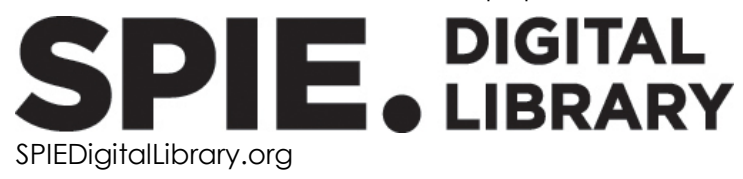

Paper Numbering: Proceedings of SPIE follow an e-First publication model. A unique citation identifier (CID) number is assigned to each article at the time of publication. Utilization of CIDs allows articles to be fully citable as soon as they are published online, and connects the same identifier to all online and print versions of the publication. SPIE uses a six-digit CID article numbering system structured as follows:

- The first four digits correspond to the SPIE volume number.

- The last two digits indicate publication order within the volume using a Base 36 numbering system employing both numerals and letters. These two-number sets start with 00, 01, 02, 03, 04, 05, 06, 07, 08, 09, OA, OB ... 0Z, followed by 10-1Z, 20-2Z, etc. The CID Number appears on each page of the manuscript. 


\title{
Contents
}

\author{
$\checkmark \quad$ Authors \\ vii Conference Committee \\ xi Introduction
}

\section{SCINTILLATORS I}

996803 High energy resolution plastic scintillator [9968-2]

\section{DETECTOR MATERIALS I}

9968 OA New xenon gamma-ray spectrometer for sorting of radioactive waste [9968-9]

9968 OC Creation of economical and robust large area MCPs by ALD method for photodetectors [9968-11]

9968 OD Effects on hard x-ray response of a double-sided Si strip detector caused by interstrip surface charge [9968-12]

9968 OE Leakage current conduction and reliability assessment of passivating thin silicon dioxide films on $\boldsymbol{n}-\mathbf{4 H}-\mathrm{SiC}$ [9968-13]

\section{SCINTILLATORS II}

9968 0J X-ray imaging with ePix100a: a high-speed, high-resolution, low-noise camera [9968-18]

9968 OK Multi-station electron scrubbing and performance testing device of large-area MCP [9968-19]

\section{SEMICONDUCTOR DETECTOR MATERIALS}

9968 OM Improved radiation detectors on $\mathbf{4 H}-\mathbf{S i C}$ epilayers by edge termination (Invited Paper) [9968-21]

9968 ON Ytterbium fluoride loaded plastic scintillators for Y-ray spectroscopy (Invited Paper) [9968-22]

\section{NEUTRON DETECTORS}

9968 OP Semiconductor neutron detectors (Invited Paper) [9968-24] 
9968 OS Thermal neutron detectors based on hexagonal boron nitride epilayers [9968-27]

\section{DETECTOR DEVICES}

9968 OT Hard $x$-ray imaging and particle detection with TIMEPIX3 (Invited Paper) [9968-28]

9968 OU The development of SiGHT: an ultra low background photosensor [9968-29]

$99680 \mathrm{~V}$ Xenon gamma-ray spectrometer for the monitoring of radon concentration for possible earthquake precursors search [9968-30]

$99680 \mathrm{X}$ Pilot production and advanced development of large-area picosecond photodetectors [9968-32]

\section{SCINTILLATORS III}

9968 OY A comparative study via Monte Carlo simulation of new inorganic scintillator $\mathrm{Cs} 2 \mathrm{HfCl} 6$ for applications in nuclear medicine, security and defense, and astrophysics (Invited Paper) [9968-33]

\section{CZT II}

996813 A model-based multiple-pinhole synthetic imager for stand-off range gamma-emitting objects [9968-38]

CZT III

996817 Controlling the growth temperature gradient and interface shape for traveling heater method growth of CdTe single crystals [9968-42]

\section{POSTER SESSION}

9968 1E Thermal conductivity studies of CdZnTe with varying Te excess [9968-49]

$9968 \mathrm{IF}$ Silicon photomultipliers detectors for next generation high-energy space telescopes [9968-50]

9968 1H Csl:Tl scintillator separated by Si grid partition wall [9968-52] 


\section{Authors}

Numbers in the index correspond to the last two digits of the six-digit citation identifier (CID) article numbering system used in Proceedings of SPIE. The first four digits reflect the volume number. Base 36 numbering is employed for the last two digits and indicates the order of articles within the volume. Numbers start with 00, 01, 02, 03, 04, 05, 06, 07, 08, 09, OA, OB...0Z, followed by 10-12, 20-2Z, etc.

Adams, Bernhard W., OX

Aoki, Toru, $1 \mathrm{H}$

Aviles, Melvin, OX

Babalola, Stephen, $1 \mathrm{E}$

Baldez, Phoenix, 13

Bennett, Brittany, 1E

Blaj, G., OJ

Bond, Justin L., OX

Burger, Arnold, OP

Bychkova, Oksana V., OV

Caragiulo, P., OJ

Chen, Henry, OY

Chen, $\mathrm{Yi}, \mathrm{ON}$

Chowdhury, Towhid A., OM

Cirignano, Leonard, OP

Craven, Christopher A., OX

Cremer, Till, OX

Delaigue, S., IF

DeRego, Paul J., 13

Dias da Cunha, Kenya Moore, 13

Dmitrenko, Valery V., OA, OV

Doan, T. C., OS

Doty, Patrick, 03

Dragone, A., OJ

Elagin, Andrey, OX

Elam, Jeffrey W., OC, OX

Ertley, Camden, OX

Fan, A., OU

Feng, Cheng, OK

Feng, Patrick, 03

Fiorillo, G., OU

Foley, Michael R., OX

Frisch, Henry, OX

Fröjdh, Christer, OT

Fukazawa, Yasushi, OD

Galbiati, C., OU

Giltnane, Dustin, 1E

Gimenez, T., 1F

Guan, M. Y., OU

Gueorguiev, Andrey, OP

Hagino, Koichi, OD

Hajagos, Tibor Jacob, ON

Haller, G., OJ

Hasi, J., OJ

Hecht, Adam A., 13

Hong, Huicong, $\mathrm{OP}$

Houret, B., IF

Jackson, Maxx, 1E

Jiang, H. X., OS
Jin, Yunxia, ON

Kenney, C. J., OJ

Kim, Hadong, OP

Kim, Jin-Sang, 17

Kishpaugh, David, ON

Knödlseder, J., IF

Kobayashi, Shogo Benjamin, OD

Koike, Akihumi, 1H

Kokubun, Motohide, OD

Korga, G., OU

Krapohl, David, OT

Kwiatkowski, M., OJ

Lacombe, K., IF

$L i, J .$, OS

Lin, J. Y., OS

Liu, Chao, ON

Liu, Jian, OK

Lyashenko, Alexey, OX

Mandal, Krishna C., OE, OM

Mane, Anil U., OC, OX

Markosyan, Gary, 03

Markovic, B., OJ

Marty, A., OS

Minot, Michael J., OC, OX

Miura, Taketo, OD

Miyake, Katsuma, OD

Mourey, V., IF

Nakano, Toshio, OD

Nakazawa, Kazuhiro, OD

Nishizawa, Junichi, $1 \mathrm{H}$

Novikov, Alexander S., OA, OV

Ohmes, Martin F., IE

Okuda, Kazufumi, OD

Oner, Cihan, OM

Pak, Rahmi O., OM

Pantic, E., OU

Pei, Qibing, ON

Petrenko, Denis V., OA, OV

Popecki, Mark A., OX

Qian, Yun-sheng, OK

Raby, Paul, OY

Ramon, P., IF

Razeto, A., OU

Renshaw, A., OU

Rossi, B., OU

Saito, Shinya, OD

Samanta, Piyas, OE

Sato, Goro, OD

Segal, J., OJ 
Shah, Kanai S., 03, OP

Shirwadkar, Urmila, 03

Shustov, Alexander E., OA, OV

Siegmund, Oswald H. W., OC, OX

Song, ChengXin, OK

Stochaj, Michael E., OX

Stowe, A. C., $1 \mathrm{E}$

Suh, Sang-Hee, 17

Suh, Youngjoon, 17

Suvorov, Y., OU

Tabata, Kento, $1 \mathrm{H}$

Tajima, Hiroyasu, OD

Takahashi, Tadayuki, OD

Takeda, Shinichiro, OD

Tang, LiMing, OK

Thungström, Göran, OT

Tomada, A., OJ

Tower, Joshua, OP

Ulin, Sergey E., OA, OV

Uteshev, Ziyaetdin M., OA, OV

van Loef, Edgar V., 03

Virmontois, C., $1 F$

Vlasik, Konstantin F., OA, OV

Wagner, Robert G., OC

Wang, H., OU

Wang, Y., OU

Watanabe, Shin, OD

Worstell, William A., OX

Yang, C. G., OU

Zhang, Yijun, OK

Zhuang, Qixin, ON

Proc. of SPIE Vol. $9968996801-6$ 


\section{Conference Committee}

Program Track Chairs

Ali M. Khounsary, Illinois Institute of Technology (United States)

Ralph B. James, Brookhaven National Laboratory (United States)

Conference Chairs

Ralph B. James, Savannah River National Laboratory (United States)

Michael Fiederle, Freiburger Materialforschungszentrum (Germany)

Arnold Burger, Fisk University (United States)

Larry Franks, Consultant (United States)

Conference Co-chair

Stephen A. Payne, Lawrence Livermore National Laboratory

(United States)

Conference Program Committee

Toru Aoki, Shizuoka University (Japan)

Jim E. Baciak Jr., University of Florida (United States)

David B. Beach, Y-12 National Security Complex (United States)

Zane W. Bell, Oak Ridge National Laboratory (United States)

Koushik Biswas, Arkansas State University (United States)

Lynn A. Boatner, Oak Ridge National Laboratory (United States)

Aleksey E. Bolotnikov, Brookhaven National Laboratory

(United States)

Edith Bourret Courchesne, Lawrence Berkeley National Laboratory (United States)

Giuseppe S. Camarda, Brookhaven National Laboratory (United States)

Bill Cardoso, Creative Electron (United States)

Henry Chen, Brimrose Corporation of America (United States)

Nerine J. Cherepy, Lawrence Livermore National Laboratory (United States)

Jeffrey J. Derby, University of Minnesota (United States)

Kim F. Ferris, Pacific Northwest National Laboratory (United States)

Petro M. Fochuk, Yuriy Fedkovych Chernivtsi National University (Ukraine)

Jan Franc, Charles University in Prague (Czech Republic)

Fei Gao, Pacific Northwest National Laboratory (United States)

Zhong He, University of Michigan (United States)

Keitaro Hitomi, Tohoku University (Japan) 
Alan Janos, U.S. Deptartment of Homeland Security (United States) Mercouri Kanatzidis, Northwestern University (United States)

Warnick J. Kernan, Pacific Northwest National Laboratory

(United States)

KiHyun Kim, Korea University College of Health Sciences

(Korea, Republic of)

Henric Krawczynski, Washington University in St. Louis (United States)

Kelvin G. Lynn, Washington State University (United States)

Krishna C. Mandal, University of South Carolina (United States)

Robert D. McLaren, Consultant (United States)

Shariar Motakef, CapeSym, Inc. (United States)

Sanjoy Mukhopadhyay, National Security Technologies, LLC (United States)

Utpal N. Roy, Brookhaven National Laboratory (United States)

Arie Ruzin, Tel Aviv University (Israel)

David J. Singh, Oak Ridge National Laboratory (United States)

Narsingh B. Singh, University of Maryland, Baltimore County (United States)

Michael R. Squillante, Radiation Monitoring Devices, Inc. (United States)

Ashley C. Stowe, Y-12 National Security Complex (United States)

Csaba Szeles, Nious Technologies Inc. (United States)

Sergey E. Ulin, National Research Nuclear University MEPhl (Russian Federation)

Edgar V. van Loef, Radiation Monitoring Devices, Inc. (United States)

Aaron L. Washington II, Savannah River National Laboratory

(United States)

Richard T. Williams, Wake Forest University (United States)

Session Chairs

1 Scintillators I

Ralph B. James, Savannah River National Laboratory (United States)

2 CZTI

Arnold Burger, Fisk University (United States)

3 Detector Materials |

Jan Franc, Charles University in Prague (Czech Republic)

4 Scintillators II

Charles L. Melcher, The University of Tennessee Knoxville

(United States)

5 Semiconductor Detector Materials

Nerine J. Cherepy, Lawrence Livermore National Laboratory

(United States) 
6 Neutron Detectors

Krishna C. Mandal, University of South Carolina (United States)

7 Detector Devices

Arnold Burger, Fisk University (United States)

8 Scintillators III

Stephen A. Payne, Lawrence Livermore National Laboratory (United States)

9 CZT II

Larry Franks, Consultant (United States)

10 CZT III

Robert D. McLaren, Consultant (United States) 
Proc. of SPIE Vol. $9968996801-10$

Downloaded From: https://www.spiedigitallibrary.org/conference-proceedings-of-spie on 25 Apr 2023 Terms of Use: https://www.spiedigitallibrary.org/terms-of-use 


\section{Introduction}

This book contains the proceedings of the SPIE Conference on Hard X-Ray, Gamma-Ray, and Neutron Detector Physics XVIII. The conference was held on August 29-31, 2016 in San Diego, CA. The conference was organized into technical sessions on cadmium zinc telluride (CZT), scintillators, detector materials, devices, and neutron detectors. A poster session was also provided.

The purpose of the conference was to provide a forum for scientists and engineers from the detector development and user communities to present and evaluate the most recent results on x-ray, gamma-ray, and neutron detectors and to discuss the requirements for a variety of radiation-sensing and imaging applications. The primary theme of the conference was on the development of improved semiconductor and scintillator radiation detectors and imaging arrays, which combine the advantages of room-temperature operation with the ability to spectrally resolve the energies of emitted $x$ - and gamma-rays, and on applications of the technology. By eliminating the cryogen, new radiation-sensing instruments, such as spectrometers, gamma cameras and radiographic systems, can be manufactured that are portable, lightweight, easy to operate, and relatively maintenance-free. Recent research and development on detectors have resulted in measurable progress in the availability of single detectors and imaging arrays. In addition, recent reports of the material properties limiting the performance of semiconductor and scintillator detectors have provided new insights and directions to address deficiencies in the crystals and devices.

Despite the limitations on efficiency and relatively high cost of current roomtemperature semiconductor detectors and new emerging scintillators, they have been increasingly deployed in systems useful for medical diagnostics, space applications, safeguarding of nuclear materials, material identification, baggage scanning, position sensing, and gamma-ray spectroscopy. Although significant progress has occurred over recent years, there is still a pressing need to lower the cost of the detectors and to increase the efficiency of the detectors while improving their spectral performance.

A total of 59 presentations, including 12 posters, were provided at the conference. Although the number of attendees varied with the session and day of week, the attendance averaged approximately 50 people with a substantial fraction of those in attendance representing organizations outside of the U.S.

This book provides detailed documentation describing a portion of the presentations. The editors hope that it will serve as an important record of the meeting, provide an update on the status of x-ray, gamma-ray, and neutron detector technology, and serve as a useful resource for those working in the field. 
The Conference Chairs would like to thank the Session Chairs and members of the Conference Program Committees, who offered their time to enlist the involvement of many researchers working in the field. We also express our indebtedness to all authors who contributed to the proceedings, and to the SPIE staff for their excellent cooperation and continuous support during the conference call, organization, and proceedings processes.

\section{Ralph B. James \\ Larry A. Franks \\ Arnold Burger \\ Michael Fiederle \\ Steve Payne}

